\title{
Soil aggregation and potential carbon and nitrogen mineralization with cover crops under tropical no-till
}

\author{
J.P.G. Rigon, A.J. Franzluebbers, and J.C. Calonego
}

\begin{abstract}
Sustainability of agriculture with no-tillage (NT) production requires appropriate cover cropping and not a simple and random approach of any cover crop species. However, relatively little is known of the long-term soil surface impacts of different cover crops in rotation with soybean (Glycine max) under NT in the tropics. We evaluated the impacts of different cover crops on soil aggregation, soil organic carbon $(\mathrm{C})$ and nitrogen $(\mathrm{N})$ fractions, and soil microbial activity of a Typic Rhodudalf at the end of 12 years under NT in São Paulo state of Brazil. Treatments included main plots during the winter dry season (triticale [ $\times$ Triticosecale] and sunflower [Helianthus annuus]) and subplots during the spring cover crop season (pearl millet [Pennisetum glaucum], sunn hemp [Crotolaria juncea], forage sorghum [Sorghum bicolor], and fallow with occasional chiseling). All eight of these treatments followed soybean in summer. Winter crop treatments had no effect on soil aggregation, but total organic $\mathrm{C}$ and $\mathrm{N}$ concentrations were greater $(p<0.05)$ with triticale than with sunflower. Across depths, soil aggregation and soil $\mathrm{C}$ and $\mathrm{N}$ fractions were generally enhanced when sunn hemp was cover crop than with fallow in the spring. Triticale followed by sunn hemp provided soil cover and fresh mineralizable residue for improving soil quality in this unfertilized $(\mathrm{N})$ soybean-based cropping system. Our results suggest that maintaining soil cover is important to improve soil aggregation and soil $\mathrm{C}$ and $\mathrm{N}$ fractions, but also the quality of organic inputs determined by cover crop species is an important factor controlling the dynamics of these soil responses.
\end{abstract}

Key words: carbon and nitrogen fractions—-diversified cropping systems—Oxisol—residue inputs

\begin{abstract}
Soil health and soil quality, although not new concepts, have attracted considerable attention recently (Mitchell et al. 2017). Key functions of soil health and associated soil carbon (C) may be modified by improved management practices, including cover cropping and no-tillage (NT), and are often mediated by a diversity of microorganisms (Franzluebbers 2016).

Minimizing soil disturbance is a critical component of conservation agriculture (CA) systems. The long-term beneficial effects of soil management with $\mathrm{CA}$ are difficult to dispute (Tiecher et al. 2017). However, CA does not mean only absence of soil disturbance or eliminating soil cultivation, and the simple adoption of NT itself does not guarantee the sustainability of agriculture, since
\end{abstract}

benefits of the approach are not universal across soils (Vandenbygaart 2016; Reicosky 2015). Monoculture crop production with fallow periods, or lack of crop rotation and insufficient soil cover, violate the conservation concepts of CA (Derpsch et al. 2014). Differences in soil and crop yield responses among studies around the world can often be attributed to quantity and quality of biomass-C inputs and not only due to the absence of tillage (Franzluebbers 2010).

Growing cover crops can be a key element of CA and play an essential role in achieving adequate surface residue cover in many regions. In addition, abundant and diverse cover crops can provide $\mathrm{C}$ and nitrogen $(\mathrm{N})$ to the next crop managed with NT to enhance soil organic carbon (SOC) accu-

Received October 24, 2019; Revised December 21, 2019; Accepted January 20, 2020. mulation (Franzluebbers 2010; Derpsch et al. 2014). In tropical regions with low fertilizer inputs, the main factor controlling SOC accumulation under NT is the contribution of $\mathrm{N}_{2}$ fixation by legume cover crops (Boddey et al.2010), as well as greater microbial populations in the rhizosphere (Chen et al. 2008). However, irregular rainfall and dry winter in tropical regions make it more difficult to maintain soil cover throughout the year (Jantalia et al. 2007). Grass residues are characterized by a high $\mathrm{C}: \mathrm{N}$ ratio and long persistence on the soil surface as a result of low decomposition rate (Teixeira et al. 2014), thereby fostering soil organic matter (SOM) accumulation and reducing mineralization (Shahbaz et al. 2017). Hence, crop rotation and the type of cover crop management system can influence SOC accumulation and its cascading effects on soil biological activity and aggregation.

Crop rotation has been suggested as a strategy to increase soil aggregation and SOC storage (Novelli et al. 2013, 2017; Lal 2015), mainly near the soil surface $(<0.1$ $\mathrm{m}$ depth) (Ruis and Blanco-Canqui 2017). However, effects are dependent on soil textural class, soil management duration, climatic conditions, and quantity and quality of crop residue.

Crop residue quality affects the extent and rate of reaction for soil microorganisms to release or immobilize inorganic $\mathrm{N}$, according to $\mathrm{C}: \mathrm{N}$ ratio and/or lignin: $\mathrm{N}$ ratio (Hadas et al. 2004; Millar and Baggs 2004; Berg and McClaugherty 2008). Knowledge of N mineralization from crop residues is important for planning supplemental quantity and timing of fertilizer $\mathrm{N}$. According to Nivelle et al. (2016), increasing the quantity and quality of crop residues in diversified cropping systems without $\mathrm{N}$ fertilization under NT may enhance soil aggregation and soil $\mathrm{C}$ and $\mathrm{N}$ contents. Conservation cropping with NT management may confer beneficial impacts on soil aggregate stability and macroaggregate formation (Bossuyt et al. 2001; Six et al.

João Paulo Gonsiorkiewicz Rigon (corresponding author) is a postdoctoral fellow at São Paulo State University, College of Agricultural Sciences, Department of Crop Science, Botucatu, São Paulo, Brazil. Alan Franzluebbers is a research ecologist with USDA Agricultural Research Service in Raleigh, North Carolina. Juliano Carlos Calonego is a professor at Department of Crop Science in São Paulo State University, College of Agricultural Sciences, São Paulo, Brazil. 
2001), as well as stimulation of soil microbial activity (Franzluebbers and Brock 2007).

Protection of $\mathrm{C}$ in stable aggregates inhibits mineralization and increases $\mathrm{C}$ retention in soil (Cambardella and Elliott 1992). Accumulation of crop residues at the soil surface provides $\mathrm{C}$ and $\mathrm{N}$ inputs and fosters a zone of greater potential soil biological activity, which can be measured from soil C and $\mathrm{N}$ mineralization under standard conditions in the laboratory (Franzluebbers et al. 2018b). However, improved aggregation may also limit $\mathrm{C}$ and $\mathrm{N}$ mineralization in soil by protection of organic material within aggregates. We hypothesized that legume cover crops would enhance soil aggregation and reduce decomposition rates of organic matter as compared with grasses as cover crops under long-term NT. Our goal was to evaluate if choice of winter crop and spring cover crop in a NT soybean production system in the Brazilian tropics would affect soil aggregation and associated soil $\mathrm{C}$ and $\mathrm{N}$ fractions.

\section{Materials and Methods}

Site Description. The experiment was established in 2003 in Botucatu, São Paulo (22 49' $\mathrm{S}$ and $\left.48^{\circ} 25^{\prime} \mathrm{W}\right)$, at an altitude of $780 \mathrm{~m}$ in a Typic Rhodudalf (Soil Survey Staff 2010). The tropical climate is mesothermal with a well-defined dry season from May to August (fall-winter in the Southern Hemisphere) and mean annual precipitation of 1,450 $\mathrm{mm}$. Soil chemical (van Raij et al.2001) and physical (Smith and Mullins 1991) characteristics of the experiment are shown in table 1.

Experimental Design. The experimental design was a randomized block with splitplot arrangement of eight treatments and four replications. Soybean (Glycine max L. Merr.) was grown in the summer in all plots (table 2). Treatments consisted of secondary-season grain crops (triticale [ $\times$ Triticosecale Wittm.] or sunflower [Helianthus annuus L.]) grown in the fall-winter as main plots $\left(256 \mathrm{~m}^{2}\right.$ each) followed by cover crops (pearl millet [Pennisetum glaucum L.], forage sorghum [Sorghum bicolor L. Moench], sunn hemp [Crotalaria juncea L.], or fallow) grown in the spring as subplots (40 $\mathrm{m}^{2}$ each). This treatment arrangement was repeated annually from 2003 to 2015 . Crop residues were maintained on the soil surface after each crop. Spring crops were chemically desiccated. Grain was harvested from main (soybean) and secondary-season crops (triticale and sunflower) and crop residues left on the field. Residue samples from each crop

\section{Table 1}

Chemical and physical properties of soil in August of 2014.

\begin{tabular}{|c|c|c|}
\hline \multirow[b]{2}{*}{ Soil properties } & \multicolumn{2}{|c|}{ Depth (m) } \\
\hline & $\begin{array}{l}0 \text { to } \\
0.1\end{array}$ & $\begin{array}{l}0.1 \text { to } \\
0.2\end{array}$ \\
\hline $\mathrm{pH}\left(\mathrm{CaCl}_{2}\right)$ & 5.1 & 4.5 \\
\hline $\mathrm{Al}\left(\mathrm{mmol}_{\mathrm{c}} \mathrm{dm}^{-3}\right)$ & 0.2 & 0.7 \\
\hline $\mathrm{Ca}\left(\mathrm{mmol}_{\mathrm{c}} \mathrm{dm}^{-3}\right)$ & 43 & 19 \\
\hline $\mathrm{Mg}\left(\mathrm{mmol}_{\mathrm{c}} \mathrm{dm}^{-3}\right)$ & 36 & 14 \\
\hline $\mathrm{K}\left(\mathrm{mmol}_{\mathrm{c}} \mathrm{dm}^{-3}\right)$ & 1.8 & 1.5 \\
\hline$P\left(\mathrm{mg} \mathrm{dm}^{-3}\right)$ & 33 & 17 \\
\hline Sand $\left(\mathrm{g} \mathrm{kg}^{-1}\right)$ & 108 & 100 \\
\hline Silt $\left(\mathrm{g} \mathrm{kg}^{-1}\right)$ & 237 & 245 \\
\hline Clay $\left(\mathrm{g} \mathrm{kg}^{-1}\right)$ & 655 & 655 \\
\hline Microporosity $\left(\mathrm{m}^{3} \mathrm{~m}^{-3}\right)$ & 0.42 & 0.41 \\
\hline Macroporosity $\left(\mathrm{m}^{3} \mathrm{~m}^{-3}\right)$ & 0.12 & 0.09 \\
\hline Bulk density $\left(\mathrm{Mg} \mathrm{m}^{-3}\right)$ & 1.32 & 1.37 \\
\hline
\end{tabular}

species were analyzed for cellulose, hemicellulose, and lignin (Silva and Queiroz 2002) (table 3). The fallow treatment had no cover crop, and plots were chisel plowed in 2003, 2009, and 2013 just before soybean planting. The mechanical chiseling was carried out using a chisel plow with seven shanks set on two parallel bars and spaced $0.60 \mathrm{~m}$ from each other within a bar, resulting in effective $0.30 \mathrm{~m}$ shank spacing. Shanks were inclined forward at $25^{\circ}$ angle, and the effective action depth was around $0.30 \mathrm{~m}$ (Calonego et al. 2017). Approximately 60 days after planting of spring cover crops, all plots were chemically desiccated with glyphosate at $2.5 \mathrm{~kg}$ a.i. $\mathrm{ha}^{-1}$, and then soybean as main cash crop was planted in $0.45 \mathrm{~m}$ wide rows targeting a population of 355,000 seeds $\mathrm{ha}^{-1}$. Each year since 2003, soybean was inoculated with Bradyrhizobium sp. and fertilized with $50 \mathrm{~kg}$ $\mathrm{ha}^{-1}$ of $\mathrm{K}_{2} \mathrm{O}$ and $50 \mathrm{~kg} \mathrm{ha}^{-1}$ of $\mathrm{P}_{2} \mathrm{O}_{5}$ as potassium chloride and triple superphosphate, respectively. No $\mathrm{N}$ fertilizer was applied since the beginning of the experiment.

Soil Sampling. For soil C and N fractions, three cores $(5 \mathrm{~cm}$ diameter at 0 to 0.1 and 0.1 to $0.2 \mathrm{~m}$ depths) were collected and composited diagonally across each subplot after soybean harvest in 2015. Soil was dried at $50^{\circ} \mathrm{C}$ and sieved to pass a screen with $2 \mathrm{~mm}$ openings. Another sampling for undisturbed soil was collected for soil characterization using a cylinder $(5.0 \mathrm{~cm}$ high $\times 4.8 \mathrm{~cm}$ wide $)$ to determine soil bulk density, total porosity, macroporosity, and microporosity. For soil aggregate analyses, soil monolith depths at 0 to 0.1 and 0.1 to $0.2 \mathrm{~m}$ were collected, gently broken into smaller fractions, and passed through a screen with $8 \mathrm{~mm}$ openings prior to drying at $50^{\circ} \mathrm{C}$ for 48 hours, and shipped to Raleigh, North Carolina, for further analyses. We oven-dried soil to standardize the procedure and avoid the confounding impacts of antecedent moisture content (Gollany et al. 1991).

Aggregate Fractionation. Dry-aggregate distribution of soil passing a screen with $4.75 \mathrm{~mm}$ openings was a necessary first step to characterize initial aggregate conditions prior to wet sieving. A $100 \mathrm{~g}$ portion of soil was placed on top of a nest of sieves (200 $\mathrm{mm} \varnothing$ with openings of $1,0.25$, and 0.053

Table 2

Crop rotation sequences from 2003 to 2015 and amount of crop residue in 2014 .

\begin{tabular}{llll}
\hline $\begin{array}{l}\text { Winter (main plot) } \\
\text { crop }\end{array}$ & $\begin{array}{l}\text { Spring (subplot) } \\
\text { cover crop }\end{array}$ & $\begin{array}{l}\text { Summer (entire area) } \\
\text { main crop }\end{array}$ & $\begin{array}{l}\text { Amount of crop residue } \\
\text { in 2014 (Mg ha } \mathbf{~}^{-\mathbf{1}} \mathbf{)} \boldsymbol{\dagger}\end{array}$ \\
\hline Triticale & Sunn hemp & Soybean & $13.14 \pm 1.3$ \\
Triticale & Pearl millet & Soybean & $11.02 \pm 0.7$ \\
Triticale & Forage sorghum & Soybean & $12.33 \pm 0.9$ \\
Triticale & Fallow* & Soybean & $9.20 \pm 0.9$ \\
Sunflower & Sunn hemp & Soybean & $11.70 \pm 0.4$ \\
Sunflower & Pearl millet & Soybean & $9.03 \pm 0.8$ \\
Sunflower & Forage sorghum & Soybean & $9.32 \pm 1.1$ \\
Sunflower & Fallow & Soybean & $8.58 \pm 0.8$ \\
\hline
\end{tabular}

Notes: Triticale $=\times$ Triticosecale. Sunflower $=$ Helianthus annuus. Sunn hemp $=$ Crotalaria juncea. Pearl millet = Pennisetum glaucum . Forage sorghum $=$ Sorghum bicolor. Soybean = Glycine max . *Occasionally chisel plowed.

†Amount of residue in year 2014 (fall-winter 2014 + spring crops 2014 + soybean 2014/2015). 


\section{Table 3}

Selected chemical characteristics of the crops in the crop rotation systems.

\begin{tabular}{lllllll}
\hline Crop & $\mathbf{C} / \mathbf{N}$ & Lignin/N & $\begin{array}{l}\mathbf{N} \\
(\%)\end{array}$ & $\begin{array}{l}\text { Hemicellulose } \\
(\%)\end{array}$ & $\begin{array}{l}\text { Cellulose } \\
(\%)\end{array}$ & $\begin{array}{l}\text { Lignin } \\
\text { (\%) }\end{array}$ \\
\hline Triticale & $96 \dagger$ & 37 & 0.47 & 20.0 & 49.2 & 17.3 \\
Sunflower & 66 & 31 & 0.67 & 9.9 & 48.0 & 21.1 \\
Soybean straw* & 61 & 41 & 0.75 & 12.0 & 44.6 & 30.4 \\
Forage sorghum & 53 & 6 & 0.87 & 34.7 & 35.4 & 5.4 \\
Pearl millet & 34 & 4 & 2.44 & 27.5 & 24.0 & 10.1 \\
Sunn hemp & 16 & 5 & 2.86 & 11.9 & 33.8 & 14.9 \\
\hline
\end{tabular}

Notes: $\mathrm{C}=$ carbon. $\mathrm{N}=$ nitrogen.

*After crop harvested.

†Data published in Raphael et al. (2016).

$\mathrm{mm})$ and shaken for 1 minute on a vibrating shaker on Level 6 (CSC Scientific Co., Fairfax, Virginia). Soil retained on each sieve and that passing the $0.053 \mathrm{~mm}$ screen was weighed to determine dry-aggregate size distribution (Franzluebbers et al. 2000).

Sieve sizes were chosen based on the assumption that the $>0.25 \mathrm{~mm}$ fraction was the most susceptible to changes in land use or management (Tisdall and Oades 1982). Water-stable aggregate distribution was determined from the reconstituted sample for dry-stable aggregation. Soil was placed on top of a nest of sieves $(175 \mathrm{~mm} \varnothing$ with openings of 1.0 and $0.25 \mathrm{~mm}$ ) and immersed directly in water with oscillation for $10 \mathrm{~min}$ utes $\left(20 \mathrm{~mm}\right.$ stroke length, 31 cycles $\mathrm{min}^{-1}$ ). Water containing soil passing the $0.25 \mathrm{~mm}$ sieve was poured over a $0.053 \mathrm{~mm}$ sieve and gently washed with a stream of water. The three sieves were placed in an oven to dry at $55^{\circ} \mathrm{C}$ for 24 hours. Dry-stable and water-stable macroaggregates were defined by the fractions $>0.25 \mathrm{~mm}$ (Elliott 1986). Meanweight diameter of dry-stable aggregate distribution $\left(\mathrm{MWD}_{\mathrm{dry}}\right)$ and mean-weight diameter of water-stable aggregate distribution $\left(\mathrm{MWD}_{\text {wet }}\right)$ were calculated by summing the products of mass fraction and mean diameter of each aggregate class, excluding the floating material (equation 1):

$$
M W D_{\text {wet or dry }}=\sum_{i=1}^{n} F_{i} \times D_{i}
$$

where $F_{i}$ is the corrected mass proportion of the stable aggregate fraction $i$ and $D_{i}$ is the mean diameter of the stable aggregate fraction $i$. Stability of mean-weight diameter was calculated as water-stable mean-weight diameter divided by dry-stable mean-weight diameter. Stability of macroaggregates $(>0.25 \mathrm{~mm})$ was calculated from fraction of macroaggregates following wet sieving divided by fraction of macroaggregates following dry sieving.

Soil Carbon and Nitrogen Fractions. Soil from sieved $(2 \mathrm{~mm})$ samples was ball-milled to a powder to determine SOC by dry combustion at $1,350^{\circ} \mathrm{C}$ (Leco CNS-2000, St. Joseph, Michigan). For mineralizable C, duplicate sieved soil samples of $50 \mathrm{~g}$ were wetted to $50 \%$ water-filled pore space (Franzluebbers and Brock 2007), placed into a $1 \mathrm{~L}$ canning jar along with vials containing $10 \mathrm{~mL}$ of $1 \mathrm{M}$ sodium hydroxide $(\mathrm{NaOH})$ to trap evolved carbon dioxide $\left(\mathrm{CO}_{2}\right)$ and water to maintain humidity, and incubated at $25^{\circ} \mathrm{C}$ for 24 days. Alkali traps were replaced at 3 and 10 days. Evolved $\mathrm{CO}_{2}$ was calculated by titrating alkali with $1 \mathrm{M}$ hydrogen chloride $(\mathrm{HCl})$ to a phenolphthalein endpoint following precipitation of carbonate with excess barium chloride $\left(\mathrm{BaCl}_{2}\right)$ and vigorous stirring. At 10 days, one of the subsamples was removed from the incubation jar, fumigated with chloroform $\left(\mathrm{CHCl}_{3}\right)$ under vacuum for one day, vapors removed, placed into a separate canning jar along with vials of alkali and water, and incubated at $25^{\circ} \mathrm{C}$ for 10 days to determine soil microbial biomass C (SMBC). Potential C mineralization was calculated from the cumulative evolution of $\mathrm{CO}_{2}$ during 24 days of incubation. Soil-test biological activity was defined as the flush of $\mathrm{CO}_{2}$ during the first 3 days of incubation (Franzluebbers et al. 2018b). Inorganic N (ammonium $\left[\mathrm{NH}_{4}-\mathrm{N}\right]+$ nitrite $\left[\mathrm{NO}_{2}-\mathrm{N}\right]$ + nitrate $\left.\left[\mathrm{NO}_{3}-\mathrm{N}\right]\right)$ was determined from the filtered extract of a $10 \mathrm{~g}$ subsample of oven-dried $\left(55^{\circ} \mathrm{C}, 48\right.$ hours $)$ and sieved $(<2$ $\mathrm{mm}$ ) soil shaken with $20 \mathrm{~mL}$ of $2 \mathrm{M} \mathrm{KCl}$ for 30 minutes using salicylate-nitroprusside and hydrazine auto-analyzer techniques (Bundy and Meisinger 1994).

Particulate organic matter was determined from the dried sample previously used for SMBC. The dried $50 \mathrm{~g}$ sample was shaken in $100 \mathrm{~mL}$ of $0.1 \mathrm{M}$ tetrasodium pyrophosphate $\left(\mathrm{Na}_{4} \mathrm{P}_{2} \mathrm{O}_{7}\right)$ for 16 hours, diluted to $1 \mathrm{~L}$ with distilled water, the suspension allowed to settle for 5 hours, and the particulate material caught on a $0.053 \mathrm{~mm}$ screen (Franzluebbers et al. 2000). Material retained on the screen was transferred to a drying bottle and weighed after oven-drying $\left(55^{\circ} \mathrm{C}\right.$, 72 hours). Afterward, sand plus organic material was ground in a ball mill for 1 minute and analyzed for total $\mathrm{C}$ and $\mathrm{N}$ using dry combustion at $1,350^{\circ} \mathrm{C}$ (Leco CNS-2000, St. Joseph, Michigan)

Data Analysis. Data were tested for homogeneity of variance and normality. Data were subjected to analysis of variance using a randomized complete block design with four replicates by SAS version 9.2 (SAS Institute Inc 2009). Differences among means were considered significant at $p \leq 0.05$. Linear regression and correlation analysis were performed among variables, and Pearson's correlation coefficients obtained. Data were plotted with SigmaPlot v. 12 (Systat Software Inc., San Jose, California). Significant associations were declared at $p \leq 0.05$.

\section{Results and Discussion}

Soil Aggregation. Winter crops in the secondary season did not influence aggregation attributes, nor was an interaction with spring cover crops significant. Meanweight diameter of dry aggregates was not affected by spring cover crop treatment, but MWD of water-stable aggregates was (table 4). Absence of a spring cover crop (fallow) resulted in lower $\mathrm{MWD}_{\text {wet }}$, MWD stability, and macroaggregate stability than sunn hemp and forage sorghum as cover crop in both soil depths (table 4). With pearl millet as cover crop, MWD stability and macroaggregate stability were greater $(p<0.05)$ than with the fallow at a depth of 0 to $0.1 \mathrm{~m}$, but not significantly different at a depth of 0.1 to $0.2 \mathrm{~m}$. In general, the fallow treatment with occasional chisel tillage caused reductions in aggregation indices of at least $15 \%$ at soil surface compared with other treatments with cover crops.

Soil aggregation attributes in both soil depths were always greater $(p<0.05)$ with sunn hemp as spring cover crop, followed at the soil surface ( 0 to $0.1 \mathrm{~m}$ depth) by pearl millet and forage sorghum. In general, soil aggregation indices were always greater at 0 to $0.1 \mathrm{~m}$ depth than at 0.1 to $0.2 \mathrm{~m}$ depth, except for dry-stable aggregation, which 
Table 4

Mean-weight diameter of dry-stable aggregates $\left(M D_{d r y}\right)$, mean-weight diameter of water-stable aggregates $\left(M \mathrm{MD}_{\text {wer }}\right)$, mean-weight diameter stability (MWD Stability), and macroaggregate stability (MS) at o to $0.1 \mathrm{~m}$ (Sur) and 0.1 to $0.2 \mathrm{~m}$ (Sub) soil depths. Mean values followed by different letters in the same column are significantly different by $t$-test (LSD) at $p<0.05$.

\begin{tabular}{|c|c|c|c|c|c|c|c|c|}
\hline \multirow[b]{2}{*}{ Treatment } & \multicolumn{2}{|c|}{$M W D_{d r y}(\mathbf{m m})$} & \multicolumn{2}{|c|}{$\mathrm{MWD}_{\text {wet }}(\mathrm{mm})$} & \multicolumn{2}{|c|}{ MWD Stability $\left(\mathrm{mm} \mathrm{mm}^{-1}\right)$} & \multicolumn{2}{|c|}{ MS $\left(\mathrm{g} \mathrm{g}^{-1}\right)$} \\
\hline & Sur & Sub & Sur & Sub & Sur & Sub & Sur & Sub \\
\hline \multicolumn{9}{|l|}{ Winter crops } \\
\hline Sunflower & 2.38 & 2.34 & 1.51 & 1.16 & 0.62 & 0.49 & 0.57 & 0.40 \\
\hline Triticale & 2.43 & 2.34 & 1.59 & 1.14 & 0.65 & 0.48 & 0.60 & 0.39 \\
\hline \multicolumn{9}{|l|}{ Spring cover crops } \\
\hline Fallow & 2.38 & 2.33 & 1.34 & $1.07 b$ & $0.55 b$ & $0.45 b$ & $0.49 b$ & $0.35 b$ \\
\hline Sunn hemp & 2.43 & 2.39 & 1.67 & $1.31 a$ & $0.68 a$ & $0.55 a$ & $0.64 a$ & $0.47 a$ \\
\hline Forage sorghum & 2.39 & 2.36 & 1.56 & $1.24 a$ & $0.65 a b$ & $0.52 a$ & $0.59 a b$ & $0.43 a$ \\
\hline Pearl millet & 2.42 & 2.27 & 1.63 & $0.99 b$ & $0.67 a$ & $0.43 b$ & $0.62 a$ & $0.32 b$ \\
\hline Source & \multicolumn{8}{|c|}{$p$-value } \\
\hline Winter (W) & 0.48 & 0.99 & 0.62 & 0.73 & 0.65 & 0.70 & 0.63 & 0.73 \\
\hline Spring (S) & 0.82 & 0.09 & 0.12 & $<0.01$ & 0.04 & $<0.01$ & 0.04 & $<0.01$ \\
\hline$W \times S$ & 0.93 & 0.24 & 0.73 & 0.61 & 0.69 & 0.78 & 0.73 & 0.73 \\
\hline
\end{tabular}

was similar between depths. Dry-stable aggregation was considered a prerequisite normalization step to account for potential differences in handling of soil during sampling and processing, and therefore, was not expected to be affected by treatments. With sunn hemp as spring cover crop, MWD, MWD stability, and macroaggregate stability at 0.1 to $0.2 \mathrm{~m}$ depth were nearly the same as values with fallow at 0 to $0.1 \mathrm{~m}$ depth.

Despite general improvements in soil aggregation attributes at the soil surface with all cover crops compared with fallow, aggregation with pearl millet as cover crop at the lower depth (0.1 to $0.2 \mathrm{~m})$ declined, reaching a level comparable with fallow. In contrast, aggregation attributes with sunn hemp and forage sorghum remained greater than with fallow at 0.1 to $0.2 \mathrm{~m}$ depth.

Soil Carbon and Nitrogen Fractions. Overall, crop rotations under long-term NT influenced soil $\mathrm{C}$ and $\mathrm{N}$ fractions mainly at the soil surface (0 to $0.1 \mathrm{~m})$. Soil organic $\mathrm{C}$ had a median value of 21.1 and $17.0 \mathrm{~g}$ $\mathrm{kg}^{-1}$ at depths of 0 to 0.1 and 0.1 to $0.2 \mathrm{~m}$, respectively. Total soil $\mathrm{N}(\mathrm{TN})$ averaged 1.91 and $1.58 \mathrm{~g} \mathrm{~kg}^{-1}$ at depths of 0 to 0.1 and 0.1 to $0.2 \mathrm{~m}$, respectively. Triticale as fall/winter crop had greater $(p<0.001)$ SOC and TN than sunflower at 0 to $0.1 \mathrm{~m}$ soil depth (table $5)$. No effect of winter crop was observed on particulate organic carbon (POC) and particulate organic nitrogen (PON), nor on any of these variables at a depth of 0.1 to $0.2 \mathrm{~m}$. Among cover crop treatments, fallow with occasional chisel tillage had lower $(p<$
0.001) SOC, TN, POC, and PON, as well as the lability of soil $\mathrm{C}$ and $\mathrm{N}$ than other cover crop treatments at a depth of 0 to $0.1 \mathrm{~m}$ (table 5). However, an interesting result on SOC and TN was greater $(p<0.05)$ concentration with fallow than with pearl millet as cover crop at a depth of 0.1 to $0.2 \mathrm{~m}$.

Unexpectedly, neither winter crop nor spring cover crop affected SMBC, net $\mathrm{N}$ mineralization, or residual inorganic $\mathrm{N}$ (data not shown). With an unprotected LSD, there was only a trend for lower net $\mathrm{N}$ mineralization and residual inorganic $\mathrm{N}$ with fallow compared with pearl millet at a depth of 0 to $0.1 \mathrm{~m}$ (table 5$)$. Further soil sampling in spring and winter seasons are suggested to assess the SMBC.

Soil-test biological activity $\left(\mathrm{CMIN}_{0-3 \mathrm{~d}}\right)$ and cumulative $\mathrm{C}$ mineralization $\left(\mathrm{CMIN}_{0-24 \mathrm{~d}}\right.$ ) at a depth of 0 to $0.1 \mathrm{~m}$ had significant interaction between winter crop and spring cover crop treatments (table 6). Sunn hemp behaved differently depending on the preceding winter crop. This cover crop had the highest and lowest $\mathrm{CMIN}_{0-3 \mathrm{~d}}$ when cultivated after triticale and sunflower, respectively (85 and $46 \mathrm{mg}$ $\left.\mathrm{kg}^{-1}, p<0.05\right)$. The same pattern was observed for $\mathrm{CMIN}_{0-24 \mathrm{~d}}\left(270\right.$ and $172 \mathrm{mg} \mathrm{kg}^{-1}, p<$ $0.05)$. Among the cover crops, fallow had the lowest CMIN $(p<0.05)$, independently of the winter crops in both evaluations.

The proportion of SOC as CMIN was greater with pearl millet and forage sorghum as spring cover crop than with fallow (data not shown). A similar trend occurred for the proportion of TN as NMIN ( $p=0.08)$.
Regression Analysis. Across soil depths, $\mathrm{CMIN}_{0-3 \mathrm{~d}}$ was most closely associated with CMIN $_{0-24 \mathrm{~d}}$ (figure $1 \mathrm{a} ; r^{2}=0.94 ; p<0.0001$ ). Other significant regressions $(p<0.0001)$ occurred between $\mathrm{CMIN}_{0-3 \mathrm{~d}}$ and NMIN (figure $1 \mathrm{~b} ; r^{2}=0.68$ ). Soil-test biological activity $\left(\mathrm{CMIN}_{0-3 \mathrm{~d}}\right)$ was also highly related with TN and SOC (figure $1 \mathrm{c} ; r^{2}=0.73$ and 0.79 , respectively), due mainly to the close association with each other (SOC and TN ${ }^{2}$ $=0.96$, data not shown]). Across winter crop and spring cover crop treatment, SMBC had highly significant association $(p<0.0001)$ with TN and SOC (figure $1 c ; r^{2}=0.76$ ).

Soil aggregation indices also had positive associations $(p<0.001)$ with TN and SOC (figure 2a through 2d). The highest Pearson's correlation coefficients were observed for MWD, MWD stability, and macroaggregate stability, ranging from $r=0.67$ to 0.70 . $\mathrm{MWD}_{\text {dry }}$ was also significantly associated ( $p$ $<0.007)$ with SOC, although the association was weak $\left(r^{2}=0.17\right)$. In general, associations were slightly greater with TN than with SOC (figure 2).

Aggregate Fractions. We did not find treatment differences in MWD of dry-stable aggregates, and this is consistent with other observations in the literature (Blanco-Canqui and Ruis 2018). According to these authors, the improvement achieved through NT may be more effective on water-stable than dry-stable aggregates.

Absence of a cover crop in the fallow treatment during the spring season likely had a greater impact on aggregation indices than occasional chisel plowing to loosen soil. We base this interpretation on observations from other studies in tropical regions (Portella et al. 2012; Seben et al. 2014). Moreover, the chisel operation likely does not reduce aggregation in the surface layer (Nunes et al. 2015), because the shanks of chisel plow can break soil along natural fracture lines without damaging natural intra-aggregate structure. In general, growing crops with aggressive root systems improves soil structure (Calonego et al. 2017). In addition, our soil sampling occurred two years after the last chisel operation, and previous investigations at the study confirmed this tillage operation resulted in immediate impacts on soil compaction and structure, but did not last to the second year following the event (Calonego et al. 2017). Hence, as compared with reduced $\mathrm{C}$ input with fallow, the continuous flow of $\mathrm{C}$ in a diverse cropping system with springtime 


\section{Table 5}

Soil organic carbon (SOC), total nitrogen (TN), particulate organic carbon (POC), particulate organic nitrogen (PON), net N mineralization during 24 days of incubation (NMIN), and residual inorganic N (RIN) at soil depths of o to 0.1 (Sur) and 0.1 to $0.2 \mathrm{~m}$ (Sub) as affected by winter crops and spring cover crops. Mean values followed by different letters in the same column are significantly different by $t$-test (LSD) at $p<0.05$.

\begin{tabular}{|c|c|c|c|c|c|c|c|c|c|c|c|c|}
\hline \multirow[b]{2}{*}{ Treatment } & \multicolumn{2}{|c|}{ SOC (mg kg-1) } & \multicolumn{2}{|c|}{ TN (mg kg-1) } & \multicolumn{2}{|c|}{ POC (mg g $\left.{ }^{-1}\right)$} & \multicolumn{2}{|c|}{ PON (mg g-1) } & \multicolumn{2}{|c|}{ NMIN (mg kg-1) } & \multicolumn{2}{|c|}{ RIN (mg kg-1) } \\
\hline & Sur & Sub & Sur & Sub & Sur & Sub & Sur & Sub & Sur & Sub & Sur & Sub \\
\hline \multicolumn{13}{|l|}{ Winter crops } \\
\hline Triticale & $21.6 a$ & 17.0 & $1.95 a$ & 1.59 & 3.7 & 1.7 & 0.24 & 0.09 & 30.3 & 15.9 & 38.7 & 27.3 \\
\hline \multicolumn{13}{|l|}{ Spring cover crops } \\
\hline Forage sorghum & $21.6 a$ & $16.5 \mathrm{bc}$ & $1.94 a$ & $1.55 b c$ & $3.8 a b$ & 1.7 & $0.25 a b$ & 0.09 & 32.2 & 16.0 & 40.1 & 25.4 \\
\hline Pearl millet & $21.8 \mathrm{a}$ & $16.3 \mathrm{c}$ & $1.98 a$ & $1.51 \mathrm{c}$ & $4.2 a$ & 1.8 & $0.28 a$ & 0.09 & 34.8 & 16.2 & 43.0 & 27.0 \\
\hline Source & $p$-value & & & & & & & & & & & \\
\hline Winter (W) & 0.03 & 0.89 & 0.04 & 0.74 & 0.13 & 0.18 & 0.17 & 0.21 & 0.54 & 0.73 & 0.71 & 0.60 \\
\hline Spring (S) & $<0.01$ & 0.04 & 0.03 & 0.02 & $<0.01$ & 0.22 & $<0.01$ & 0.24 & 0.07 & 0.35 & 0.09 & 0.82 \\
\hline
\end{tabular}

cover crop leads to humification of organic compounds and close association of $\mathrm{C}$ with aggregates and soil particles, which is responsible for the formation of stable organic mineral complexes (Golchin et al. 1994).

Greatest aggregation indices in both soil depths from sunn hemp are in agreement with results reported by Hubbard et al. (2013) and Blanco-Canqui and Ruis (2018). According to these authors, sunn hemp in crop rotations using NT improves soil physical properties. This cover crop also increased macroporosity in a previous investigation from our long-term study (Calonego et al. 2017). Addition of readily mineralizable substrates causes an increase in aggregate stability (Schlecht-Pietsch et al. 1994; Roldan et al. 1994). Similarly, adding sunn hemp and late-maturing soybean cover crops to NT winter wheat (Triticum aestivum L.) reduced soil compaction and increased MWD ${ }_{\text {wet }}$ and SOC compared with NT without cover crops after 15 years in a temperate region (Blanco-Canqui et al. 2011). High-quality residues may increase the rate of soil aggregation (Six et al. 2001) and help to explain the result from sunn hemp. Sunn hemp as cover crop resulted in greater soybean yield (10-year average) at this site (Calonego et al. 2017) and led to greater concentration of SOC and other organic matter fractions (Raphael et al. 2016). Hence, this study supports the theory that crop diversity via rotation of grasses with legumes can improve aggregate stability, thereby confirming the results of other studies (Pérès et al. 2013; Lange et al. 2015; Comin et al. 2018).
Our results suggest that maintaining soil cover may not be enough to improve soil aggregation, but the quality of organic inputs can be an important factor in controlling aggregation and soil organic $\mathrm{C}$ and $\mathrm{N}$ dynamics. Although cover crop effects on soil aggregation and SOM have been observed before (Blanco-Canqui et al. 2011; Comin et al. 2018; Blanco-Canqui and Ruis 2018), few studies have emphasized these impacts under long-term NT in the tropics. As described by Fujisaki et al. (2018), a long period of evaluation is needed after a change in management practices to document the effectiveness of these practices on SOC stocks.

Soil Carbon and Nitrogen Fractions. Absence of crop residues with the spring fallow treatment that received occasional chisel tillage was a driving factor for the limited accumulation of soil $\mathrm{C}$ and $\mathrm{N}$ fractions (SOC, $\mathrm{TN}, \mathrm{POC}$, and $\mathrm{PON}$ ), and these results are in agreement with other studies (Raphael et

\section{Table 6}

Interaction between winter crops and spring cover crops on carbon mineralization (CMIN) at 0 to 3 days and 0 to 24 days. Means followed by different lowercase letters in a column are significantly different between winter crops and means followed by different uppercase letters in a row are significantly different among spring cover crops at $p<0.05$. Least significant difference (LSD) is for all treatment combinations across winter crops and spring cover crops at $p<0.05$.

\begin{tabular}{|c|c|c|c|c|c|c|c|c|}
\hline \multirow[b]{2}{*}{$\begin{array}{l}\text { Winter } \\
\text { crops }\end{array}$} & \multicolumn{4}{|c|}{ CMIN 0 to 3 days $\left(\mathrm{mg} \mathrm{kg}^{-1}\right)$} & \multicolumn{4}{|c|}{ CMIN 0 to 24 days $\left(\mathrm{mg} \mathrm{kg}^{-1}\right)$} \\
\hline & $\begin{array}{l}\text { Pearl } \\
\text { millet }\end{array}$ & $\begin{array}{l}\text { Forage } \\
\text { sorghum }\end{array}$ & $\begin{array}{l}\text { Sunn } \\
\text { hemp }\end{array}$ & Fallow & $\begin{array}{l}\text { Pearl } \\
\text { millet }\end{array}$ & $\begin{array}{l}\text { Forage } \\
\text { sorghum }\end{array}$ & $\begin{array}{l}\text { Sunn } \\
\text { hemp }\end{array}$ & Fallow \\
\hline Sunflower & $77 \mathrm{~A}$ & $83 \mathrm{~A}$ & $46 b B$ & 48B & $273 A$ & $268 \mathrm{~A}$ & $172 b B$ & $158 \mathrm{~B}$ \\
\hline Triticale & $82 \mathrm{~A}$ & $76 A B$ & $85 a A$ & $63 B$ & 267 & 242 & $270 a$ & 213 \\
\hline LSD & 19 & & & & 73 & & & \\
\hline
\end{tabular}

al. 2016; Bayer et al. 2000). Elsewhere, fallow or bare soil has led to in situ SOC mineralization and a substantial decrease in SOC content (Paradelo et al. 2016). Our data suggest the presence of crop residues on the soil surface enhances soil responses under NT, not only the lack of soil disturbance. Hence, the amount and quality of residues covering soil appears to impact soil $\mathrm{C}$ and $\mathrm{N}$ attributes (Frasier et al. 2016), which are key features of CA systems (Derpsch et al. 2014). These results indicate that in a long-term NT system without $\mathrm{N}$ fertilization, legume cover crops may be necessary to enhance soil $\mathrm{C}$ and $\mathrm{N}$ fractions and to maintain soil microbial functional activities (Nivelle et al. 2016). Greater cover crop $N$ inputs may be a reasonable substitute for synthetic $\mathrm{N}$ fertilizers, as also discussed in a recent review (Kaye and Quemada 2017).

Availability of $\mathrm{N}$ can be one of the main factors limiting SOC sequestration (Wieder 


\section{Figure 1}

Association of soil-test biological activity $\left(\mathrm{CMIN}_{0-3 \mathrm{~d}}\right)$ and soil microbial biomass carbon (SMBC) with cumulative carbon mineralization ( $\mathrm{CMIN}_{0-24 \mathrm{~d}}$, net nitrogen mineralization (NMIN), total nitrogen (TN), and soil organic carbon (SOC) across soil depths of o to 0.1 and 0.1 to $0.2 \mathrm{~m}$. (a)

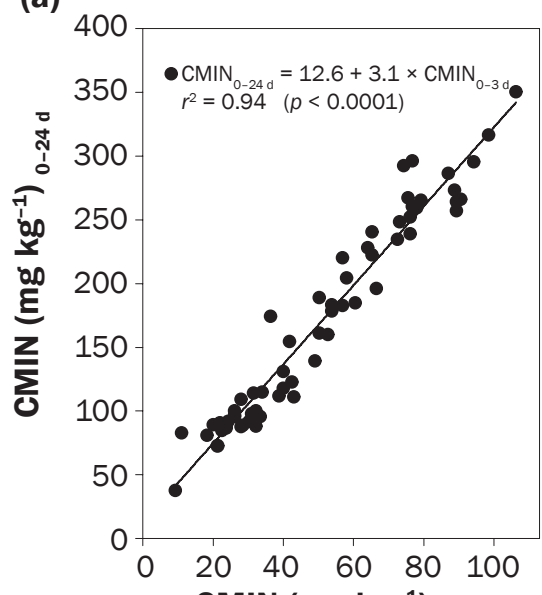

(c)

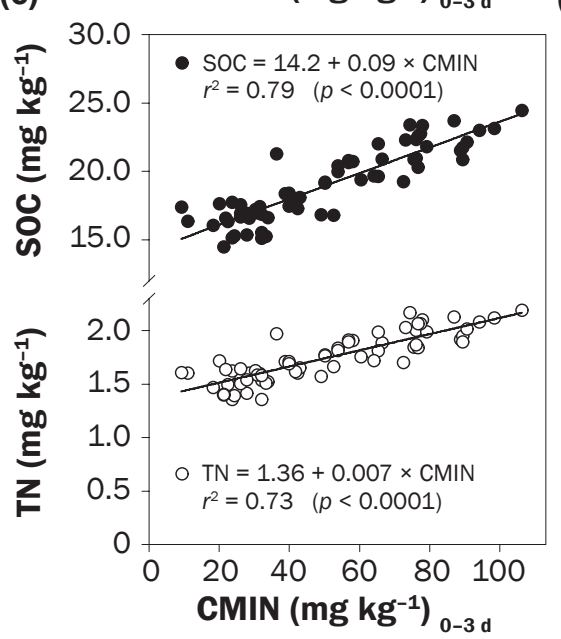

(b)

(d)

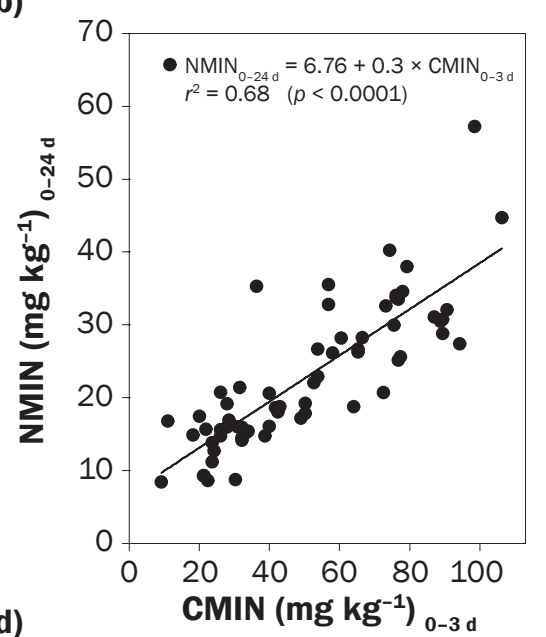

triticale residue than from sunflower residue may pose a limitation to soil decomposers (table 3). Consequently, slower residue decomposition and higher residue persistence may enhance physical soil protection, as previously reported (Rigon et al. 2018). In contrast, fresh $\mathrm{C}$ available from sunflower resulted in greater soil-test biological activity than from triticale (table 6). In addition, the dry winter season in this region often limits sunflower's growth compared to triticale, leading to insufficient soil residue cover after spring crop seeding. Lack of residue cover could also help explain the lower SOC and TN under sunflower as winter crop (table 5). Additionally, cropping sunn hemp (high $\mathrm{N}$ residue content) after a limited amount of sunflower crop residue might intensify decomposition, known as the priming effect (Qiao et al. 2016). A similar behavior in the absence of cover crop with fallow supported this explanation of rapid mineralization. According to Shahbaz et al. (2018), some studies ignore interactions of labile $\mathrm{C}$ and fresh or decaying crop residues commonly present in field conditions.

The fallow treatment with absence of residue may have led to slightly lower SMBC (although not statistically significant). The observed trend is consistent with other observations that soil management has a significant impact on SMBC (Zhang et al. 2018). Sampling soil at shallower depth than 0 to 0.1 $\mathrm{m}$ may have detected a stronger effect.

Regression Analysis. The strong relationship between $\mathrm{CMIN}_{0-3 \mathrm{~d}}$ and $\mathrm{CMIN}_{0-24 \mathrm{~d}}$ provides further support for using a rapid assessment of potential soil biological activity (Franzluebbers 2016). It also confirms a similar relationship across 57 field trials on tall fescue pasture (Franzluebbers et al. 2018a). Soil-test biological activity $\left(\mathrm{CMIN}_{0-3 \mathrm{~d}}\right)$ could be considered a good predictor of soil surface changes in soil $\mathrm{C}$ and $\mathrm{N}$ fractions (SOC, TN, POC, PON, and $\mathrm{SMBC}$ ) under a variety of crop rotations under long-term NT. Soil C and N cycles are related to the processes of mineralization and immobilization, indicating a strong relationship between soil $\mathrm{C}$ and $\mathrm{N}$ transformations and soil $\mathrm{CO}_{2}$ flux (Balota and Auler 2011). Several other studies have documented this close relationship of various soil $\mathrm{C}$ and $\mathrm{N}$ fractions with soil-test biological activity (Franzluebbers and Brock 2007; Franzluebbers et al. 2018b). According to these authors, soil-test biological activity is also more rapid and inexpensive than other procedures. 
The relation between $\mathrm{C}$ stabilization and aggregation with $\mathrm{C}$ inputs from crop residue has been observed before (Lal 2015), and our data confirm this relationship with increases in soil aggregation indices and soil $\mathrm{C}$ and $\mathrm{N}$ fractions by winter cover crops under NT. Greater crop residue C inputs usually result in greater concentration of SOC. High-intensity cropping with three crops per year having different quantities and qualities of residue $\mathrm{C}$ and $\mathrm{N}$ inputs helps explain differences in SOC and TN after 12 years of NT soybean cropping systems. These results support other research that show cover crops have important potential to improve the sustainability of soybean cropping systems (Delgado and Gantzer 2015), with multiple ecosystem service benefits (Daryanto et al. 2018).

\section{Summary and Conclusions}

This study focused on establishing the impacts of different crop rotation under NT for 12 years on soil aggregation, soil organic $\mathrm{C}$ and $\mathrm{N}$ fractions, and soil microbial activity of a Typic Rhodudalf in a tropical region of Brazil. Our results provide a unique perspective on $\mathrm{C}$ and $\mathrm{N}$ fractions in response to different winter and spring crop options.

Cover crop residues are essential to increase SOC and $\mathrm{TN}$ in tropical soils under NT. However, our results suggest that not only is soil cover necessary to maintain or improve soil aggregation and $\mathrm{C}$ and $\mathrm{N}$ fractions, but the quality of organic inputs derived from cover crop species is also important to affect these changes. Low $\mathrm{C}: \mathrm{N}$ ratio residues of sunn hemp confer both labile $\mathrm{C}$ and $\mathrm{N}$ inputs and stabilization to build soil resilience and quality physical protection when rotated with other high $\mathrm{C}: \mathrm{N}$ ratio residues. In contrast, fallow with bare soil and occasional chisel tillage led to in situ SOC mineralization as a driving factor for reduced accumulation of soil $\mathrm{C}$ and $\mathrm{N}$ fractions. These results are important for enhancing the sustainability of agriculture in tropical regions.

\section{Acknowledgements}

The project was supported by the São Paulo State Foundation for Research Support (FAPESP) under grants 15/23389-6 and 13/23359-4. We thank North Carolina State University for hosting a portion of this research and express our gratitude to Ellen Leonard (research technician at North Carolina State University), Erin Silva (research technician with USDA Agricultural Research Service), and

\section{Figure 2}

Association of total nitrogen (TN) and soil organic carbon (SOC) with mean-weight diameter of dry-stable aggregates $\left(M W D_{d r y}\right)$, mean-weight diameter of wet-stable aggregates $\left(M D_{\text {wet }}\right)$, mean-weight diameter stability (MWD Stability), and macroaggregate stability (MS) across soil depths of 0 to 0.1 and 0.1 to $0.2 \mathrm{~m}$.

(a)

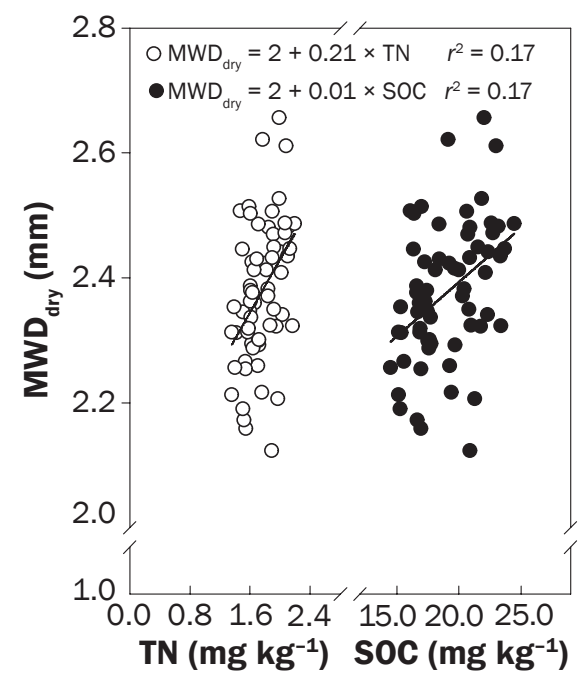

(c)

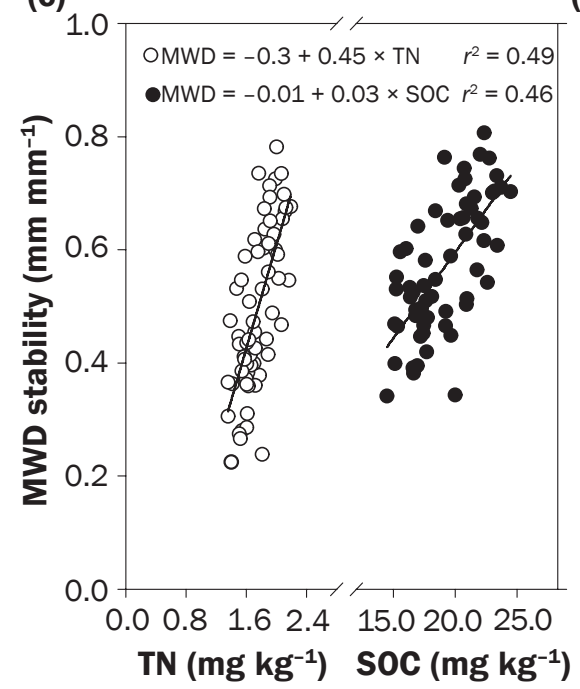

(b)

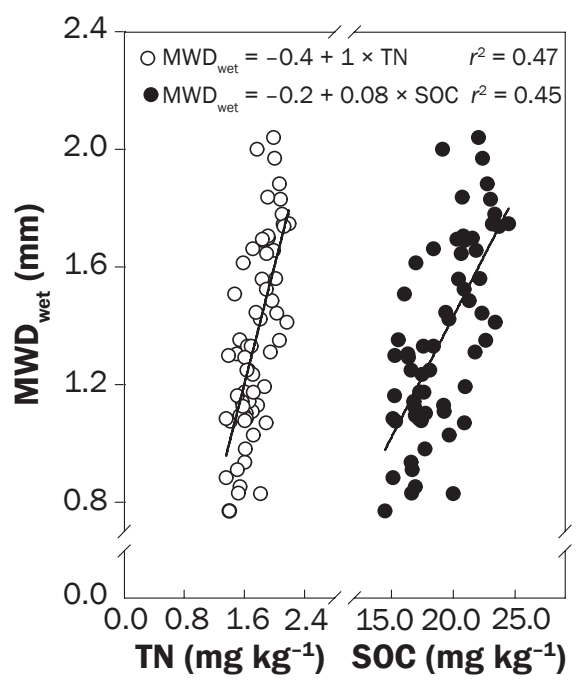

(d)

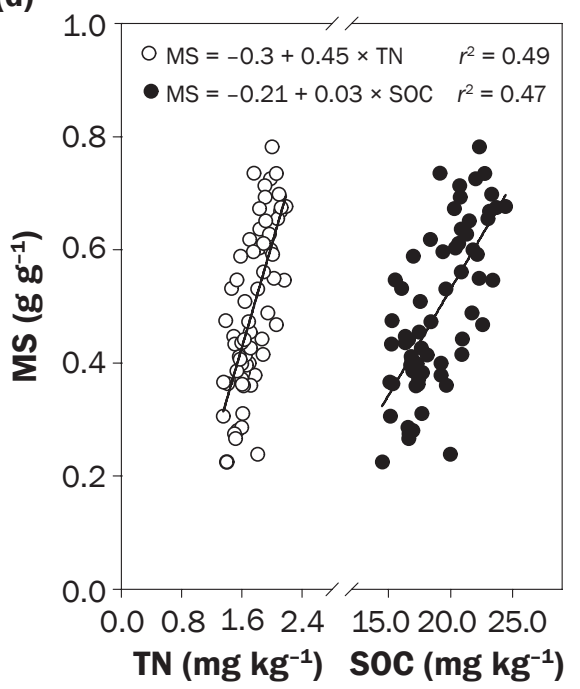

Isabela Gomes (graduate research assistant, University of Kentucky) for technical support.

\section{References}

Balota, E.L., and P.A.M. Auler. 2011. Soil microbial biomass under different management and tillage systems of permanent intercropped cover species in an orange orchard. Revista Brasileira de Ciência do Solo 35:1873-1883

Bayer, C., L. Martin-Neto, J. Mielniczuk, and C.A. Ceretta. 2000. Effect of no-till cropping systems on soil organic matter in a sandy clay loam Acrisol from southern Brazil monitored by electron spin resonance and nuclear magnetic resonance. Soil and Tillage Research 53:95-104.
Berg, B., and C. Mcclaugherty. 2008. Plant Litter: Decomposition, Humus Formation, Carbon Sequestration, 2nd edition. Heidelberg: Springer-Verlag. Bertrand, I., B. Chabbert, B. Kurek, and S. Recous. 2006.

Can the biochemical features and histology of wheat residues explain their decomposition in soil? Plant and Soil 281:291-307.

Blanco-Canqui, H., M.M. Mikha, D.R. Presley, and M.M. Claassen. 2011. Addition of cover crops enhances no-till potential for improving soil physical properties. Soil Science Society of America Journal 75:1471-1482.

Blanco-Canqui, H., and S.J. Ruis. 2018. No-tillage and soil physical environment. Geoderma 15:164-200.

Boddey, R.M., C.P. Jantalia, P.C. Conceição, J.A. Zanatta, C. Bayer, J. Mielniczuk, J. Dieckow, H.P. Santos, J.E. 
Denardin, C. Aita, S.J. Giacomini, B.J.R. Alves, and S. Urquiaga. 2010. Carbon accumulation at depth in Ferralsols under zero-till subtropical agriculture. Global Change \& Biology 16:784-795.

Bossuyt, H., K. Denef, J. Six, S.D. Frey, R. Merckx, and K. Paustian. 2001. Influence of microbial populations and residue quality on aggregate stability. Applied Soil Ecology 16:195-208.

Bundy, L.G., and J.J. Meisinger. 1994. Nitrogen availability indices. In Methods of Soil Analysis, ed. R. W.Weaver, J.S. Angle, and P.S. Bottomley, Part 1, SSSA Book Series 5, 951-984. Madison, WI: Soil Science Society of America.

Calonego, J.C., J.P. Raphael, J.P.G. Rigon, L. Oliveira Neto, and C.A. Rosolem. 2017. Soil compaction management and soybean yields with cover crops under no-till and occasional chiseling. European Journal of Agronomy 85:31-37.

Cambardella, C.A., and E.T. Elliott. 1992. Particulate soil organic-matter changes across a grassland cultivation sequence. Soil Science Society America Journal 56:777-783.

Chen, M., B. Chen, and P. Marschner. 2008. Plant growth and soil microbial community structure of legumes and grasses grown in monoculture or mixture. Journal of Environmental Sciences 20:1231-1237.

Christensen, B.T. 2001. Physical fractionation of soil and structural and functional complexity in organic matter turnover. European Journal of Soil Science 52:345-353.

Comin, J.J., L.B. Ferreira, L.H. Santos, L.P. Koucher, L.N. Machado, E. Santos Jr., A.L. Mafra, C.K.M. Souza, G. Brunetto, and A. Loss. 2018. Carbon and nitrogen contents and aggregation index of soil cultivated with onion for seven years using crop successions and rotations. Soil and Tillage Research 184:195-202.

Cotrufo, M.F., M.D. Wallenstein, C.M. Boot, K. Denef, and E.A. Paul. 2013. The Microbial Efficiency-Matrix Stabilization (MEMS) framework integrates plant litter decomposition with soil organic matter stabilization: Do labile plant inputs form stable soil organic matter? Global Change Biology 19:988-995, https://doi. org/10.1111/gcb.12113.

Daryanto, S., B. Fu, L. Wang, P.A. Jacinthe, and W. Zhao. 2018. Quantitative synthesis on the ecosystem services of cover crops. Earth-Sciences Reviews 185:357-373.

Delgado, J.A., and C.J. Gantzer. 2015. The 4Rs for cover crops and other advances in cover crop management for environmental quality. Journal of Soil and Water Conservation 70(6):142A-145A, https://doi. org/10.2489/jswc.70.6.142A.

Derpsch, R., A.J. Franzluebbers, S. W. Duiker, D.C. Reicosky, K. Koeller, W.G. Sturny, J.C.M. Sá, and K. Weiss. 2014. Why do we need to standardize no-tillage research? Soil and Tillage Research 137:16-22.

Elliott, E.T. 1986. Aggregate structure and carbon, nitrogen, and phosphorus in native and cultivated soils. Soil Science Society of America Journal 50:627-633.
Franzluebbers, A.J. 2010. Achieving soil organic carbon sequestration with conservation agricultural systems in the southeastern United States. Soil Science Society of America Journal 74:347-357.

Franzluebbers, A.J. 2016. Should soil testing services measure soil biological activity? Agricultural \& Environmental Letters 1:150009, doi:10.2134/ael2015.11.0009.

Franzluebbers, A.J., and B.G. Brock. 2007. Surface soil responses to silage cropping intensity on a Typic Kanhapludult in the piedmont of North Carolina. Soil and Tillage Research 93:126-137.

Franzluebbers, A.J., S. Pehim-Limbu, and M.H. Poore. 2018a. Soil-test biological activity with the flush of $\mathrm{CO}_{2}$ : IV. Fall-stockpiled tall fescue yield response to applied nitrogen. Agronomy Journal 110:2033-2049.

Franzluebbers, A.J., M.R. Pershing, C. Crozier, D. Osmond, and M. Schroeder-Moreno. 2018b. Soil-test biological activity with the flush of $\mathrm{CO}_{2}: \mathrm{I}$. C and $\mathrm{N}$ characteristics of soils in corn production. Soil Science Society of America Journal 82:685-695.

Franzluebbers, A.J., and J.A. Stuedemann. 2002. Particulate and non-particulate fractions of soil organic carbon under pastures in the Southern Piedmont USA. Environmental Pollution 116:S53-S62.

Franzluebbers, A.J., S.F. Wright, and J.A. Stuedemann. 2000. Soil aggregation and glomalin under pastures in the Southern Piedmont USA. Soil Science Society of America Journal 64:1018-1026.

Frasier, I., E. Noellemeyer, N. Amiotti, and A. Quiroga. 2017. Vetch-rye biculture is a sustainable alternative for enhanced nitrogen availability and low leaching losses in a no-till cover crop system. Field Crops Research 214:104-112.

Frasier, I., E. Noellemeyer, E. Figuerola, L. Erijman, H. Permingeat, and A. Quiroga. 2016. High quality residues from cover crops favor changes in microbial community and enhance $\mathrm{C}$ and $\mathrm{N}$ sequestration. Global Ecology and Conservation 6:242-256.

Fujisaki, K., T. Chevallier, L. Chapuis-Lardy, A. Albrecht, T. Razafimbelo, D. Masse, Y.B. Ndour, and J.L. Chotte. 2018. Soil carbon stock changes in tropical croplands are mainly driven by carbon inputs: A synthesis. Agriculture, Ecosystem \& Environment 259:147-158.

Golchin, A., J.M. Oades, J.O. Skjemstad, and P. Clarke. 1994. Soil structure and carbon cycle. Australian Journal of Soil Research 32:1043-1068.

Gollany, H.T., T.E. Schumacher, P.D. Evenson, M.J. Lindstrom, and G.D. Lemme. 1991. Aggregate stability of an eroded and desurfaced Typic Argiustoll. Soil Science Society of America Journal 55:811-816.

Hadas, A., L. Kautsky, M. Goek, and E.E. Kara. 2004. Rates of decomposition of plant residues and available nitrogen in soil, related to residue composition through simulation of carbon and nitrogen turnover. Soil Biology and Biochemistry 36:255-266.

Hubbard, R.K., T.C. Strickland, and S. Phatak. 2013. Effects of cover crop systems on soil physical properties and carbon/nitrogen relationships in the coastal plain of southeastern USA. Soil and Tillage Research 126:276-283.

Jantalia, C.P., D.V.S. Resck, B.R.J. Alves, L. Zotarelli, S. Urquiaga, and R.M. Boddey. 2007. Tillage effect on C stocks of a clayey Oxisol under a soybean-based crop rotation in the Brazilian Cerrado region. Soil and Tillage Research 95:97-109.

Kaye, J.P., and M. Quemada. 2017. Using cover crops to mitigate and adapt to climate change: A review. Agronomy for Sustainable Development 37:1-4.

Lal, R. 2015. Soil carbon sequestration and aggregation by cover cropping. Journal of Soil and Water Conservation 70(6):329-339, https://doi.org/10.2489/jswc.70.6.329.

Lange, M., N. Eisenhauer, C.A. Sierra, H. Bessler, C. Engels, R.I. Griffiths, P.G. Mellado-Vazquez, A.A. Malik, J. Roy, S. Scheu, S. Steinbeiss, B.C. Thomson, S.E. Trumbore, and G. Gleixner. 2015. Plant diversity increases soil microbial activity and soil carbon storage. Nature Communications 6:6707.

Lavallee, J.M., J.L. Soong, and M.F. Cotrufo. 2019. Conceptualizing soil organic matter into particulate and mineral-associated forms to address global change in the 21st century. Global Change Biology 00:1-13.

Millar, N., and E.M. Baggs. 2004. Chemical composition, or quality of agroforestry residues influences $\mathrm{N}_{2} \mathrm{O}$ emissions after their addition to soil. Soil Biology and Biochemistry 36:935-943.

Mitchell, J., A. Shrestha, K. Mathesius, K.M. Scow, R.J. Southard, and R.L. Haney. 2017. Cover cropping and no-tillage improve soil health in an arid irrigated cropping system in California's San Joaquin Valley, USA. Soil Tillage and Research 165:325-335.

Nivelle, E., J.Verzeaux, H. Habbib, Y. Kuzyakov, G. Decocq, D. Roger, J. Lacoux, J. Duclercq, F. Spicher, J.R. NavaSaucedo, M. Catterou, F. Dubois, and T. Tetu. 2016. Functional response of soil microbial communities to tillage, cover crops and nitrogen fertilization. Applied Soil Ecology 108:147-155.

Novelli, L.E., O.P. Caviglia, and G. Piñeiro. 2017. Increased cropping intensity improves crop residue inputs to the soil and aggregate-associated soil organic carbon stocks. Soil and Tillage Research 165:128-136.

Novelli, L.E., O.P. Caviglia, M.G. Wilson, and M.C. Sasal. 2013. Land use intensity and cropping sequence effects on aggregate stability and C storage in a Vertisol and a Mollisol. Geoderma 195-196:260-267.

Nunes, M.R., J.E. Denardin, E.A. Pauletto, A. Faganello, and L.F.S. Pinto. 2015. Mitigation of clayey soil compaction managed under no-tillage. Soil and Tillage Research 148:119-126.

Paradelo, R., F.V. Oort, P. Barré, D. Billiou, and C. Chenu. 2016. Soil organic matter stabilization at the pluri-decadal scale: Insight from bare fallow soils with contrasting physicochemical properties and macrostructures. Geoderma 275:48-54. 
Pérès, G., D. Cluzeau, S. Menasseri, J.F. Soussana, H. Bessler, C. Engels, M. Habekost, G. Gleixner, A. Weigelt, W.W. Weisser, S. Scheu, and N. Eisenhauer. 2013. Mechanisms linking plant community properties to soil aggregate stability in an experimental grassland plant diversity gradient. Plant and Soil 373:285-299.

Portella, C.M.R., M.F. Guimaraes, C. Feller, I.C.B. Fonseca, and J.T. Filho. 2012. Soil aggregation under different management systems. Revista Brasileira de Ciência do Solo 36:1868-1877.

Qiao, N., X. Xu, Y. Hu, E. Blagodatskaya,Y. Liu, D. Schaefer, and Y. Kuzyakov. 2016. Carbon and nitrogen additions induce distinct priming effects along an organic-matter decay continuum. Scientific Reports 6:1-8.

Raphael, J.P.A., J.C. Calonego, D.M.B.P. Milori, and C.A Rosolem. 2016. Soil organic matter in crop rotations under no-till. Soil and Tillage Research 155:45-53.

Reicosky, D.C. 2015. Conservation tillage is not conservation agriculture. Journal of Soil and Water Conservation 70(5):103A-107A, https://doi. org/10.2489/jswc.70.5.103A.

Rigon, J.P.G., J.C.C. Calonego, C.A. Rosolem, and N. La Scala Jr. 2018. Cover crop rotations in no-till system: Short-term $\mathrm{CO}_{2}$ emissions and soybean yield. Scientia Agricola 75:18-26.

Roldan,A., F. Garcia-Orenes, and A. Lax. 1994.An incubation experiment to determine factors involving aggregation changes in an arid soil receiving urban refuses Soil Biology and Biochemistry 26:1699-1707.

Ruis, S., and H. Blanco-Canqui. 2017. Cover crops could offset crop residue removal effects on soil carbon and other properties: A review. Agronomy Journal 109:1785-1805.

SAS Institute Inc. 2009. The SAS System for Windows. SAS 9.2. Cary, NC: SAS Institute.

Schlecht-Pietsch, S., U. Wagner, and T.H. Anderson. 1994. Changes in composition of soil polysaccharides and aggregate stability after carbon amendments to different textured soils. Applied Soil Ecology 1:145-154.

Seben Jr., G.F., J.E. Cora, and R. Lal. 2014. The effects of land use and soil management on the physical properties of an oxisol in Southeast Brazil. Revista Brasileira de Ciência do Solo 38:1245-1255.

Shahbaz, M., A. Kumar, Y. Kuzyakov, G. Börjesson, and E. Blagodatskaya. 2018. Interactive priming effect of labile carbon and crop residues on SOM depends on residue decomposition stage: Three-source partitioning to evaluate mechanisms. Soil Biology and Biochemistry 126:179-190.

Shahbaz, M., Y. Kuzyakov, M. Sanaullah, F. Heitkamp, V. Zelenev,A. Kumar, and E. Blagodatskaya. 2017. Microbial decomposition of soil organic matter is mediated by quality and quantity of crop residues: Mechanisms and thresholds. Biology and Fertility Soils 53:287-301.

Silva, D.J., and A.C. Queiroz. 2002. Food Analysis: Chemical and Biological Methods, 3rd edition. UFV,Viçosa, MG, Brazil (in Portuguese)
Six, J., A. Carpentier, C. Kessel, R. Merckx, D. Harris, W.R. Horwath, and A. Luscher. 2001. Impact of elevated CO2 on soil organic matter dynamics as related to changes in aggregate turnover and residue quality. Plant and Soil 234:27-36.

Smith, K.A., and C.E. Mullins. 1991. Soil Analysis: Physical Methods. New York: Marcel Dekker, Inc.

Soil Survey Staff. 2010. Keys to Soil Taxonomy, 11th edition. Washington, DC: USDA Natural Resources Conservation Service.

Teixeira, R.A., T.G. Soares, A.R. Fernandes, A.M. de S. Braz. 2014. Grasses and legumes as cover crop in no-tillage system in northeastern Pará Brazil. Acta Amazônica 44:411-418.

Tiecher, T., A. Calegari, L. Caner, and D.S. Rheinheimer 2017. Soil fertility and nutrient budget after 23-years of different soil tillage systems and winter cover crops in a subtropical Oxisol. Geoderma 308:78-85.

Tisdall, J.M., and J.M. Oades. 1982. Organic matter and water-stable aggregates in soils. European Journal of Soil Science 33:141-163.

van Raij, B., J.C.Andrade, H. Cantarella, and J.A. Quaggio. 2001 Chemical analysis for evaluation of the fertility of tropical soils. Instituto Agronômico, Campinas (In Portuguese).

Vandenbygaart, A.J. 2016. The myth that no-till can mitigate global climate change. Agriculture, Ecosystem \& Environment 216:98-99.

Wieder, W.R., C.C. Cleveland, W.K. Smith, and K. ToddBrown. 2015. Future productivity and carbon storage limited by terrestrial nutrient availability. Nature Geoscience 8:441-444.

Zhang, Z., S. Liang, J. Wang, X. Zhang, M. Mahamood, J.Yu, X. Zhang, A. Liang, and W. Liang. 2018. Tillage and crop succession effects on soil microbial metabolic activity and carbon utilization in a clay loam soil. European Journal of Soil Biology 88:97-104. 